Article

\title{
Four New Monoterpenoid Glycosides from the Flower Buds of Magnolia biondii
}

\author{
Wei-Sheng Feng ${ }^{1,2, *}$, Yu-Huan He ${ }^{1,2}$, Xiao-Ke Zheng ${ }^{1,2}$, Jian-Chao Wang ${ }^{1,2}$, Yan-Gang Cao ${ }^{1,2}$, \\ Yan-Li Zhang ${ }^{1,2}$ and Kai Song ${ }^{1,2}$ \\ 1 Collaborative Innovation Center for Respiratory Disease Diagnosis and Treatment \& Chinese Medicine \\ Development of Henan Province, Henan University of Chinese Medicine, Zhengzhou 450046, China; \\ 13071020601@163.com (Y.-H.H.); zhengxk.2006@163.com (X.-K.Z.); 15238397097@163.com (J.-C.W.); \\ caoyangang1987@126.com (Y.-G.C.); zyl2013hnzy@163.com (Y.-L.Z.); songky5901@163.com (K.S.) \\ 2 School of Pharmacy, Henan University of Chinese Medicine, Zhengzhou 450046, China \\ * Correspondence: fwsh@hactcm.edu.cn; Tel./Fax: +86-371-6568-0011
}

Academic Editor: Derek J. McPhee

Received: 19 April 2016; Accepted: 30 April 2016; Published: 3 June 2016

\begin{abstract}
Four new monoterpenoid glycosides 1-4, named magnoliaterpenoid A-D, were isolated from a $50 \%$ aqueous acetone extract of flower buds of Magnolia biondii, along with one known compound, ( $\left.1^{\prime} R, 3^{\prime} S, 5^{\prime} R, 8^{\prime} S, 2 Z, 4 E\right)$-dihydrophaseic acid 3-O- $\beta$-D-glucopyranoside (5). Their structures and relative configuration were identified by extensive spectroscopic analysis (IR, UV, MS, 1D and 2D NMR). The aglycones of these four new compounds possess seven-membered rings systems, which are very rare. A plausible biosynthetic route for the four new compounds was proposed via the biogenetic isoprene rule. Compounds 1, 2, 3, and 4 showed no antimicrobial activity at the concentration range of $1.95-250 \mu \mathrm{g} / \mathrm{mL}$.
\end{abstract}

Keywords: Magnoliaceae; flower buds of Magnolia biondii; monoterpenoid glycosides; biosynthetic route

\section{Introduction}

The genus Magnolia (family Magnoliaceae) includes about 90 species worldwide, mainly distributed in tropical and temperate regions of Asia and North America to South America. In China, there are about 30 species, mostly distributed in the southern and northern provinces of China [1]. Flos Magnoliae, the flower buds of M. biondii, M. denudata or M. sprengeri, which is unique to China and mostly distributed in the Henan, Hubei, Zhejiang, Anhui, and Shanxi provinces, has been used as a traditional Chinese medicine for more than 1500 years to treat nasal congestion, headaches, sinusitis, and allergic rhinitis [2-4]. Its volatile oil has also been processed into all kinds of cosmetics which are widely used in China [4]. It has been reported to possess extensive anti-allergy [5,6], anti-inflammatory [7], anti-angiogenic [8], anti-platelet aggregation [9,10], antimicrobial [11] and antioxidant activities $[12,13]$. Several types of compounds have been isolated from the plant, including lignans [9], neolignans [9], sesquiterpenoids [14], alkaloids [15,16], and flavonoids [15,16]. In order to further investigate the active components of the herb, a systematic phytochemical study was carried out on the 50\% aqueous acetone extract of flower buds of Magnolia biondii. As a result, four new monoterpenoid glycosides1-4, named magnoliaterpenoid A-D (Figure 1), were isolated and structurally identified, along with a known sesquiterpenoid glycoside, $\left(1^{\prime} R, 3^{\prime} S, 5^{\prime} R, 8^{\prime} S, 2 Z, 4 E\right)$ dihydrophaseic acid 3-O- $\beta$-D-glucopyranoside (5). Herein, the isolation and structural elucidation of compounds 1-4 are reported, as well as their antimicrobial activity. 


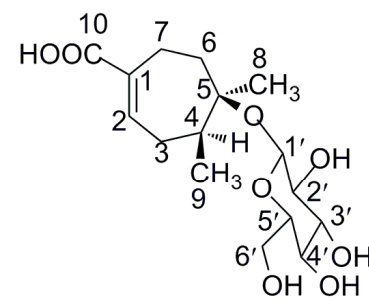

1

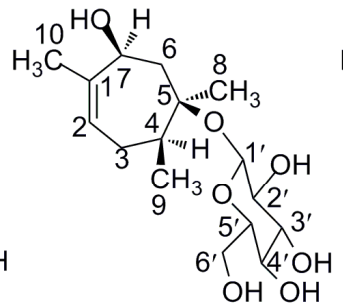

2

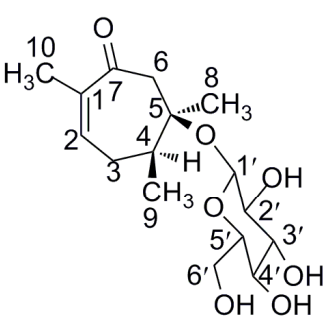

3

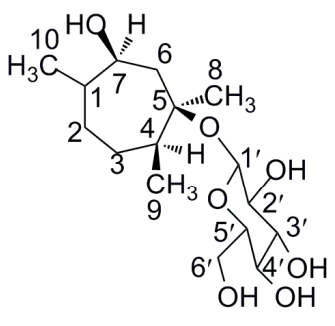

4

Figure 1. Structures of compounds 1-4.

\section{Results and Discussion}

\subsection{Structure Elucidation of Compounds $\mathbf{1}-\mathbf{4}$}

Compound 1, obtained as a colorless gum, was determined to have the molecular formula $\mathrm{C}_{16} \mathrm{H}_{26} \mathrm{O}_{8} \mathrm{Cl}$ by HRESIMS ( $\mathrm{m} / z$ 381.1301 [M + Cl] ${ }^{-}$, calcd. 381.1310), with four degrees of unsaturation. Its UV spectrum showed an absorption maximum at $217 \mathrm{~nm}$, indicating the presence of an $\alpha, \beta$-unsaturated carbonyl moiety. The IR spectrum supported the presence of hydroxyl $\left(3367 \mathrm{~cm}^{-1}\right)$, carbonyl $\left(1682 \mathrm{~cm}^{-1}\right)$ and double bond $\left(1652 \mathrm{~cm}^{-1}\right)$ groups. The ${ }^{1} \mathrm{H}-\mathrm{NMR}$ spectroscopic data of 1 (Table 1) displayed the existence of two methyl singlets $\left[\delta_{\mathrm{H}} 1.25(3 \mathrm{H}, \mathrm{s}, \mathrm{H}-8), 1.23(3 \mathrm{H}, \mathrm{br} . \mathrm{s}, \mathrm{H}-9)\right]$ and one olefinic proton $\left[\delta_{\mathrm{H}} 6.98(1 \mathrm{H}, \mathrm{t}, J=2.2,4.9 \mathrm{~Hz}, \mathrm{H}-2)\right]$ (See the Supplementary Materials). Figures S1-S36 showing the ${ }^{1} \mathrm{H}-\mathrm{NMR},{ }^{13} \mathrm{C}-\mathrm{NMR}$, DEPT, HSQC, HMBC, ${ }^{1} \mathrm{H}-{ }^{1} \mathrm{H}$ COSY, NOESY, HR-ESI-MS, UV and IR spectra of compounds 1-4 can be found in the Supplementary Materials.

Table 1. ${ }^{1} \mathrm{H}$ - and ${ }^{13} \mathrm{C}-\mathrm{NMR}$ data for compounds $1-4\left(500 / 125 \mathrm{MHz}\right.$, in $\left.\mathrm{CD}_{3} \mathrm{OD}\right)$.

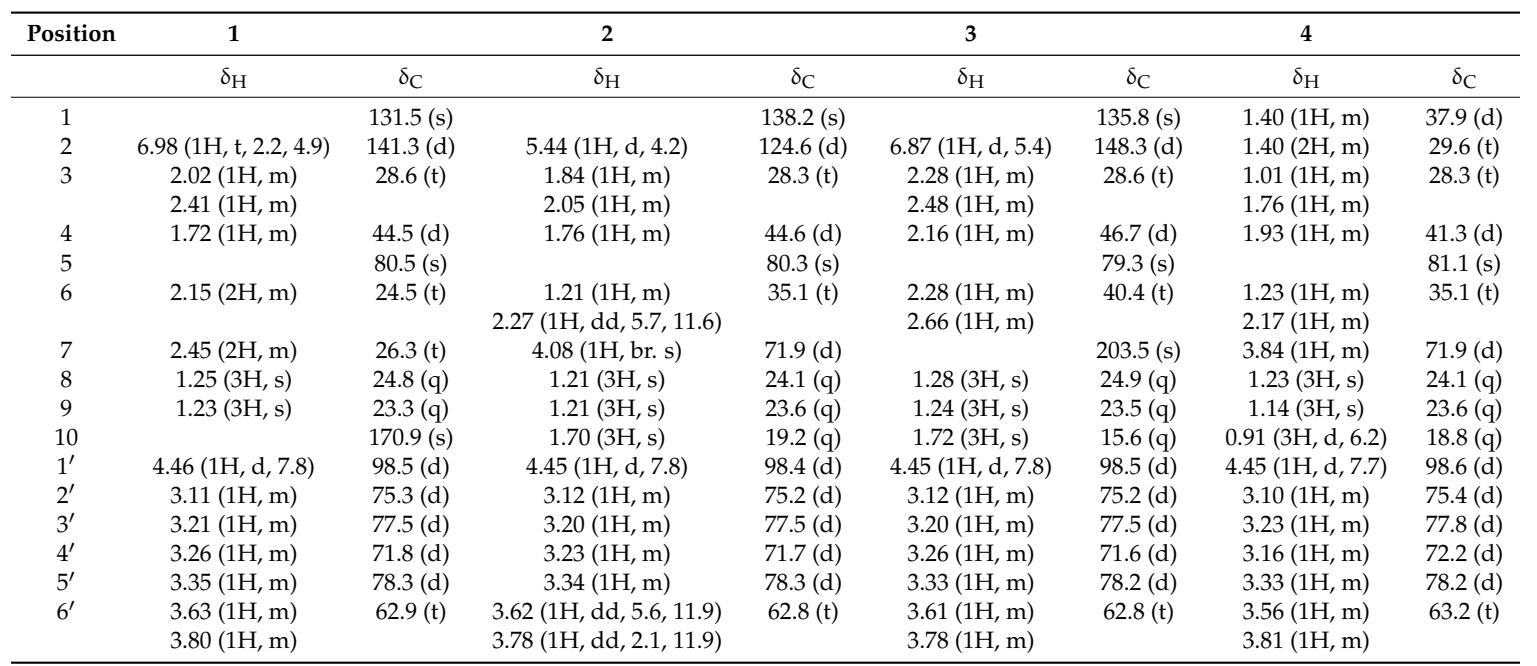

Closer examination of the ${ }^{1} \mathrm{H} /{ }^{13} \mathrm{C} /{ }^{1} \mathrm{H}^{1} \mathrm{H}$ COSY / HSQC / HMBC NMR data (Table 1) obtained for 1 revealed the presence of a glucose moiety [ $\delta 4.46\left(\mathrm{H}-1^{\prime}\right), 98.5\left(\mathrm{C}-1^{\prime}\right) ; 3.11\left(\mathrm{H}-2^{\prime}\right), 75.3\left(\mathrm{C}-2^{\prime}\right) ; 3.21$ $\left(\mathrm{H}-3^{\prime}\right)$, $\left.77.5\left({\left.\mathrm{C}-3^{\prime}\right)}^{\prime}\right) 3.26\left(\mathrm{H}-4^{\prime}\right), 71.8\left(\mathrm{C}-4^{\prime}\right) ; 3.35\left(\mathrm{H}-5^{\prime}\right), 78.3\left(\mathrm{C}-5^{\prime}\right) ; 3.80\left(\mathrm{H}-6^{\prime} \mathrm{a}\right), 3.63\left(\mathrm{H}-6^{\prime} \mathrm{b}\right), 62.9\left(\mathrm{C}-6^{\prime}\right)\right]$, along with 10 carbon resonances, including two methyl [ $\delta_{C} 24.8(\mathrm{C}-8), 23.3(\mathrm{C}-9)$ ], three methylene [ $\delta_{C} 28.6(\mathrm{C}-3), 24.5(\mathrm{C}-6), 26.3(\mathrm{C}-7)$ ], two methine [ $\delta_{C} 141.3(\mathrm{C}-2), 44.5(\mathrm{C}-4)$ ], one carbonyl [ $\delta_{C} 170.9$ (C-10)], one oxygenated quaternary carbon $\left[\delta_{C} 80.5(\mathrm{C}-5)\right]$ and one olefinic quaternary carbon $\left[\delta_{C} 131.5\right.$ (C-1)]. Apart from one double bond, one carbonyl and one glucose moiety, the remaining unsaturation of 1 required it must contain a ring. Inspection of the ${ }^{1} \mathrm{H}-$ and ${ }^{13} \mathrm{C}-\mathrm{NMR}$ spectra of 1 indicated a monoterpenoid glycoside with a structure similar to that of paeoveitol B [17]. The 7.8 Hz coupling constant for the anomeric proton $\mathrm{H}^{-1}{ }^{\prime}$ of the glucose at $\delta_{\mathrm{H}} 4.46$ confirmed its axial orientation. Acid hydrolysis and GC-MS analysis of the corresponding thiazolidine derivative substantiated the sugar unit as being $\beta$-D-glucose. In the ${ }^{1} \mathrm{H}-{ }^{1} \mathrm{H}$ COSY spectrum (Figure 2), the correlations of $\mathrm{H}-2 / \mathrm{H}-3 / \mathrm{H}-4$ 
and H-6/H-7 displayed the key spin systems. In the HMBC spectrum (Figure 2), the correlation from $\mathrm{H}-8$ to $\mathrm{C}-5$ indicated that the $8-\mathrm{CH}_{3}$ was located to $\mathrm{C}-5$; the correlation from $\mathrm{H}-9$ to $\mathrm{C}-4$ indicated that the $9-\mathrm{CH}_{3}$ was connected to $\mathrm{C}-4$; the correlation from $\mathrm{H}-1^{\prime}$ to $\mathrm{C}-5$ indicated that the $\beta$-D-glucose was linked to C-5; the correlations from $\mathrm{H}-2$ and $\mathrm{H}-7$ to $\mathrm{C}-10$ indicated that the carbonyl (C-10) was linked to $\mathrm{C}-1$; the oxygenated quaternary carbon (C-5) was located between $\mathrm{C}-4$ and $\mathrm{C}-6$ from the HMBC correlations from H-4 and H-6 to C-5. The relative configuration of compound 1 was established by the NOESY experiment (Figure 3) in which the correlation of H-4 and H-8 was observed. Thus, the structure of compound 1 was determined to be as shown in Figure 1, and it was assigned the trivial name magnoliaterpenoid A.

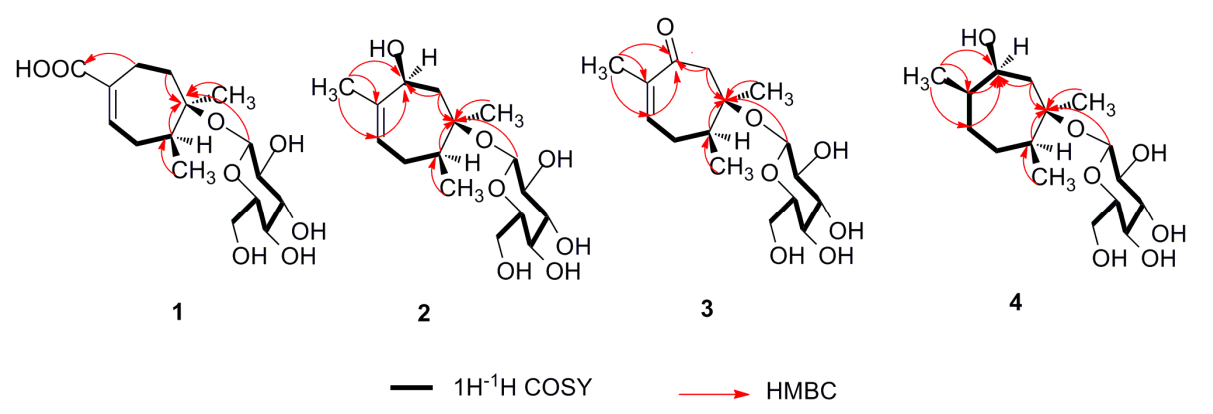

Figure 2. Key COSY and HMBC correlations of compounds 1-4.

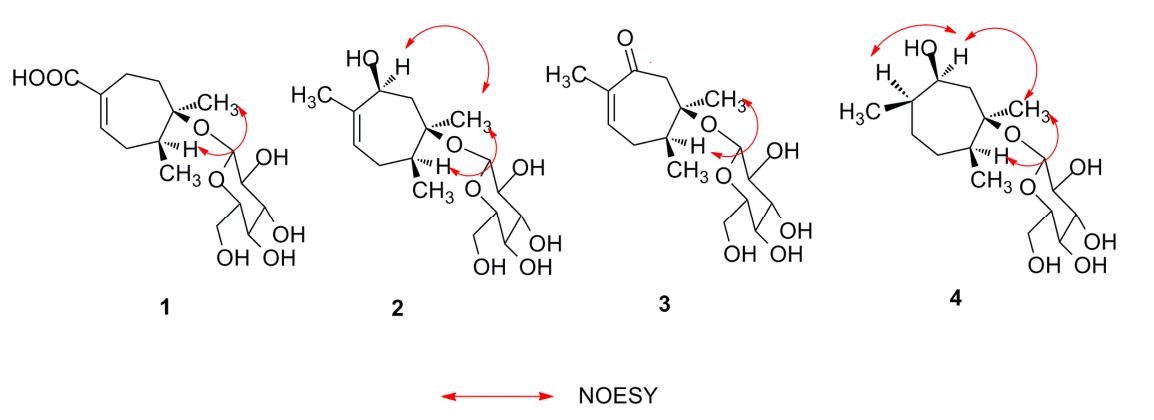

Figure 3. Key NOESY correlations of compounds 1-4.

Compound 2 was isolated as a colorless gum and had a molecular formula $\mathrm{C}_{16} \mathrm{H}_{28} \mathrm{O}_{7} \mathrm{Cl}$ by HRESIMS ( $\mathrm{m} / \mathrm{z} 367.1519\left[\mathrm{M}+\mathrm{Cl}^{-}{ }^{-}\right.$, calcd. 367.1518), indicating three degrees of unsaturation. The IR spectrum showed the presence of hydroxyl $\left(3345 \mathrm{~cm}^{-1}\right)$ and double bond $\left(1385 \mathrm{~cm}^{-1}\right)$ groups. The ${ }^{1} \mathrm{H}-\mathrm{NMR}$ spectroscopic data of 2 (Table 1 ) revealed the existence of three methyl singlets [ $\delta_{\mathrm{H}} 1.21$ $(3 \mathrm{H}, \mathrm{s}, \mathrm{H}-8), 1.21(3 \mathrm{H}$, br. s, H-9), $1.70(3 \mathrm{H}, \mathrm{s}, \mathrm{H}-10)]$ and one olefinic proton $\left[\delta_{\mathrm{H}} 5.44(1 \mathrm{H}, \mathrm{d}, J=4.2 \mathrm{~Hz}\right.$, $\mathrm{H}-2)$ ] (See the Supplementary Materials). Comparison of its ${ }^{13} \mathrm{C}-\mathrm{NMR}$ and DEPT data with those of compound 1 indicated that the two compounds possessed a similar skeleton. One of the differences between these two compounds was that the methylene signal at C-7 $\left(\delta_{C} 26.3\right)$ in 1 was replaced by an oxygenated methine at C-7 $\left(\delta_{C} 71.9\right)$ in 2 , which was established by the HMBC correlations (Figure 2) from H-2, H-6 and $\mathrm{H}-10$ to C-7, along with the ${ }^{1} \mathrm{H}-{ }^{1} \mathrm{H}$ COSY correlations (Figure 2) of H-6/H-7. The other main difference was that the carbonyl at C-10 $\left(\delta_{C} 170.9\right)$ in 1 was replaced by a methyl at C-10 $\left(\delta_{C} 19.2\right)$ in 2 , which was determined on the basis of the HMBC correlations (Figure 2) from $\mathrm{H}-10$ to $\mathrm{C}-1, \mathrm{C}-2$ and C-7. The relative configuration of compound 2 was deduced from the NOESY experiment (Figure 3) in which the correlationof $\mathrm{H}-4 / \mathrm{H}-8$ and $\mathrm{H}-7 / \mathrm{H}-8$ was detected. Similarly, the sugar unit of compound 2 was confirmed as $\beta$-D-glucose using the same method as for compound 1. Therefore, the structure of $\mathbf{2}$ was assigned as shown in Figure 1, and it was given the trivial name magnoliaterpenoid $\mathrm{B}$.

Compound 3 was isolated as a colorless gum and had a molecular formula $\mathrm{C}_{16} \mathrm{H}_{26} \mathrm{O}_{7} \mathrm{Cl}$ by HRESIMS $\left(m / z\right.$ 365.1357 [M + Cl] ${ }^{-}$, calcd. 365.1361), with four degrees of unsaturation. Its UV spectrum showed an absorption maximumat $240 \mathrm{~nm}$, indicating the presence of an $\alpha, \beta$-unsaturated carbonyl 
moiety. The IR spectrum supported the presence of hydroxyl $\left(3364 \mathrm{~cm}^{-1}\right)$, carbonyl $\left(1655 \mathrm{~cm}^{-1}\right)$ and double bond $\left(1368 \mathrm{~cm}^{-1}\right)$ groups. The ${ }^{1} \mathrm{H}-\mathrm{NMR}$ spectroscopic data of 3 (Table 1$)$ revealed the existence of three methyl singlets $\left[\delta_{\mathrm{H}} 1.28(3 \mathrm{H}, \mathrm{s}, \mathrm{H}-8), 1.24(3 \mathrm{H}, \mathrm{br} . \mathrm{s}, \mathrm{H}-9), 1.72(3 \mathrm{H}, \mathrm{s}, \mathrm{H}-10)\right]$ and one olefinic proton $\left[\delta_{\mathrm{H}} 6.87(1 \mathrm{H}, \mathrm{d}, J=5.4 \mathrm{~Hz}, \mathrm{H}-2)\right]$ (See the Supplementary Materials). The ${ }^{13} \mathrm{C}-\mathrm{NMR}$ and DEPT spectroscopic data of $\mathbf{3}$ (Table 1 ) were highly similar to those of $\mathbf{2}$. The only difference between compound 2 and 3 was that the oxygenated methine at $C-7\left(\delta_{C} 71.9\right)$ in 2 was replaced by a carbonyl at C-7 $\left(\delta_{C} 203.5\right)$ in 3, which was established by the HMBC correlations (Figure 2) from H-2, H-6 and H-10 to C-7. The relative configuration of compound 3 was assigned by the NOESY experiment (Figure 3) in which the correlation of H-4 and H-8 was observed. Similarly, the sugar unit of compound 3 was also confirmed as $\beta$-D-glucose using the same method as for compound $\mathbf{1}$. Therefore, the structure of $\mathbf{3}$ was established as shown in Figure 1, and the compound was trivially named magnoliaterpenoid C.

Compound 4 was isolated as a colorless gum. Its molecular formula was established as $\mathrm{C}_{16} \mathrm{H}_{30} \mathrm{O}_{7} \mathrm{Na}$ by HRESIMS $\left(\mathrm{m} / \mathrm{z} 357.1878\left[\mathrm{M}+\mathrm{Na}^{+}\right.\right.$, calcd. 357.1883), with two degrees of unsaturation. The IR spectrum displayed the existence of hydroxyl $\left(3362 \mathrm{~cm}^{-1}\right)$ groups. The ${ }^{1} \mathrm{H}-\mathrm{NMR}$ spectroscopic data of 4 (Table 1) supported the existence of three methyl singlets $\left[\delta_{\mathrm{H}} 1.23(3 \mathrm{H}, \mathrm{s}, \mathrm{H}-8), 1.14(3 \mathrm{H}, \mathrm{br} . \mathrm{s}, \mathrm{H}-9)\right.$, $0.91(3 \mathrm{H}, \mathrm{d}, J=6.2 \mathrm{~Hz}, \mathrm{H}-10)]$ (See the Supplementary Materials). Critical analysis of ${ }^{13} \mathrm{C}-\mathrm{NMR}$ and DEPT spectroscopic data of 4 (Table 1 ) demonstrated that its structure was closely related to that of compound 2, except that the double bond at C-1 $\left(\delta_{C} 138.2\right)$ and C-2 $\left(\delta_{C} 124.6\right)$ in 2 was reduced to a methane at $C-1\left(\delta_{C} 37.9\right)$ and a methylene at $C-2\left(\delta_{C} 29.6\right)$ respectively in 4 , which was established by the HMBC correlations (Figure 2) from $\mathrm{H}-10$ to $\mathrm{C}-1$ and $\mathrm{C}-2$, along with the ${ }^{1} \mathrm{H}-{ }^{1} \mathrm{H}$ COSY correlations (Figure 2) of H-1 and H-2. The relative configuration of compound 4 was similar to compound 2 , which was deduced from the NOESY experiment (Figure 3) in which the correlation of H-4/H-8, H-7/H-8 and $\mathrm{H}-1 / \mathrm{H}-7$ was detected. Similarly, the sugar unit of compound 4 was also confirmed as $\beta$-D-glucose using the same method as for compound 1. Thus, the structure of 4 was established as shown in Figure 1, and the compound was given the trivial name magnoliaterpenoid D.

The identity of compound $\mathbf{5}$ was determined by spectroscopic analysis and comparison with literature data [18].

\subsection{Plausible Biogenetic Pathway}

Since the aglycones of these four new compounds contained 10 carbon atoms and belonged to the monoterpenoid class of compounds, we propose a plausible biosynthetic route via the biogenetic isoprene rule, as shown in Scheme 1.

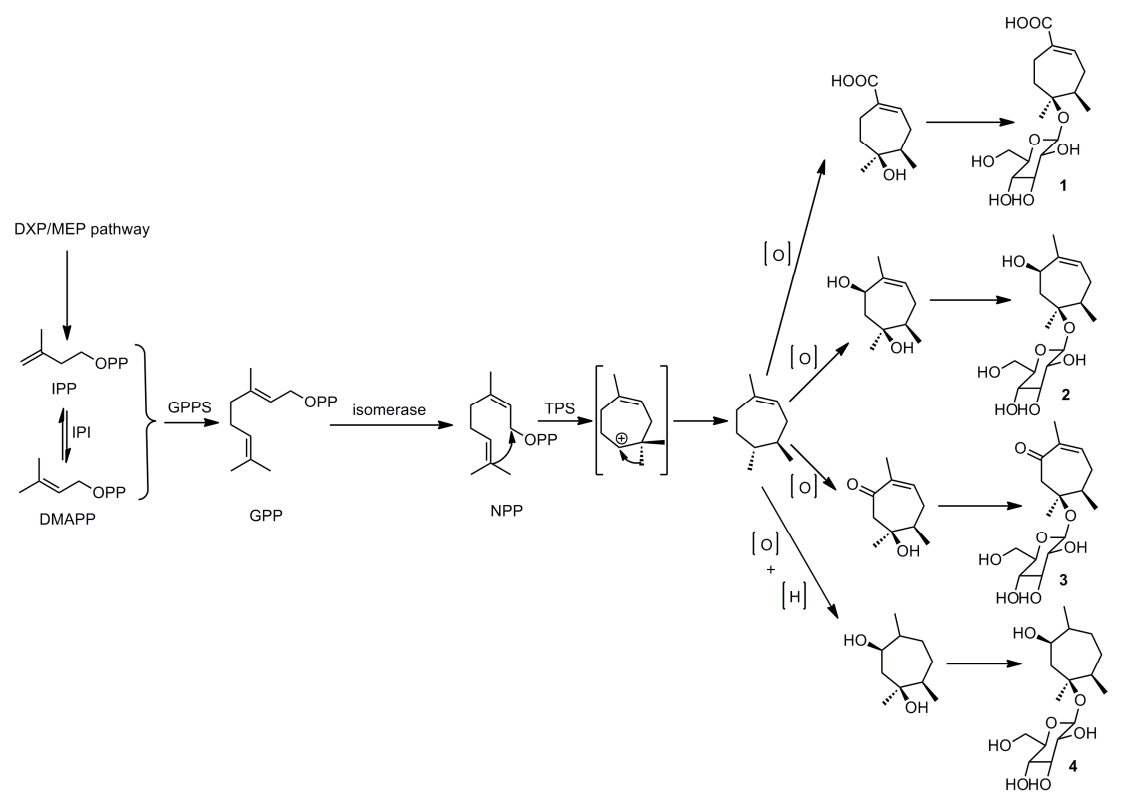

Scheme 1. Plausible biogenetic route of $1-4$. 


\subsection{Antimicrobial Activity}

The four new compounds were tested for their antimicrobial activity against Gram-positive and negative bacteria and fungi at the concentration range of 1.95-250 $\mu \mathrm{g} / \mathrm{mL}$. None of them exhibited antimicrobial activity at the tested concentrations.

\section{Experimental Section}

\subsection{General Procedures}

Optical rotations were measured on an AP-IV polarimeter (Rudolph, NJ, USA). UV spectra were measured with a Thermo EVO 300 spectrometer (Thermo Fisher Scientific, Madison, WI, USA). IR spectra were recorded on a Thermo Nicolet IS 10 spectrometer (Thermo Fisher Scientific). NMR spectra were scanned on an Avance III spectrometer (500 MHz for ${ }^{1} \mathrm{H}-\mathrm{NMR}$ and $125 \mathrm{MHz}$ for ${ }^{13} \mathrm{C}-\mathrm{NMR}$, Bruker, Zug, Switzerland). HR-ESI-MS was recorded on a Bruker MicroTOF-Q II spectrometer (Bruker Daltonics, Bremen, Germany). GC analysis was carried out on a Shimadzu GC-MS-QP2010E instrument (Shimadzu Corporation, Tokyo, Japan) using a RXI-5 ms capillary column $(30 \mathrm{~m} \times 0.25 \mathrm{~mm}$ $\times 0.25 \mu \mathrm{m}$, Restek, Bellefonte, PA, USA). Preparative HPLC was performed on a LC-3000 instrument (Chuangxintongheng, Beijing, China) equipped with a UV-3000 detector using YMC HPLC columns $(5 \mu \mathrm{m}, 10.0 \times 250 \mathrm{~mm}$ and $5 \mu \mathrm{m}, 20.0 \times 250 \mathrm{~mm})$, with a flow rate of $2.0 \mathrm{~mL} / \mathrm{min}$ and $8.0 \mathrm{~mL} / \mathrm{min}$, respectively. Column chromatography was performed using DiaionHP-20 (Mitsubishi Chemical

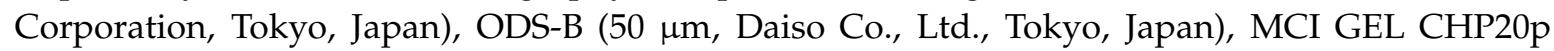
(75-150 $\mu \mathrm{m}$, Mitsubishi Chemical Corporation), and Toyopearl HW-40 (TOSOH Corporation, Tokyo, Japan). Thin-layer chromatography was carried out on self-made silica gel G (Qingdao Marine Chemical Industry, Qingdao, China) plates. The chemical reagents were supplied by Beijing Chemical Plant (Beijing, China) and Tianjin No. 3 Reagent Plant (Tianjin, China).

\subsection{Plant Material}

The flower buds of Magnolia biondii were collected from Nanzhao, Henan Province, China, and identified by Prof. Cheng-Ming Dong of the Henan University of Traditional Chinese Medicine, China. A voucher specimen (No. 20140609) has been deposited in Department of Natural Medicinal Chemistry, School of Pharmacy, Henan University of Chinese Medicine.

\subsection{Extraction and Isolation}

The air-dried flower buds of Magnolia biondii $(5.0 \mathrm{~kg})$ were extracted with aqueous acetone $(50 \% v / v, 3 \times 20 \mathrm{~L})$ at room temperature. The combined solutions were evaporated under vacuum to give a crude extract (463 g). The crude extract was suspended in $\mathrm{H}_{2} \mathrm{O}(2 \mathrm{~L})$ and then successively extracted with petroleum ether, EtOAc and $n$ - $\mathrm{BuOH}(2 \mathrm{~L} \times 5)$, respectively. The $n$ - $\mathrm{BuOH}$ fraction $(60.0 \mathrm{~g})$ was subjected to Diaion HP-20 column chromatography $(10.0 \times 60.0 \mathrm{~cm})$ and eluted with EtOH- $\mathrm{H}_{2} \mathrm{O}(0: 100,20: 80,40: 60,80: 20,95: 5$, v/v, each $20 \mathrm{~L})$ to afford five fractions (Fr. I-Fr. V). Fr. II $(14.0 \mathrm{~g})$ was then subjected to ODS column chromatography $(4.0 \times 30.0 \mathrm{~cm})$ and eluted successively with a $\mathrm{MeOH}-\mathrm{H}_{2} \mathrm{O}(0: 100,5: 95,10: 90,15: 85,20: 80,25: 75,35: 65,45: 55,100: 0, v / v$, each $1.5 \mathrm{~L})$ gradient to give nine fractions (Fr. 1-Fr. 9). Fr. 6 (1.3 g) was further separated by Toyopearl HW-40 column chromatography $(2.0 \times 50.0 \mathrm{~cm})$ with $\mathrm{MeOH}-\mathrm{H}_{2} \mathrm{O}(25: 75)$ as the eluent to obtain eight subfractions (Fr. 6A-Fr. 6H). Fr. 6B (50.0 mg) was further purified by preparative HPLC on a YMC HPLC column $\left(5 \mu \mathrm{m}, 20.0 \times 250 \mathrm{~mm}\right.$, flow rate $8 \mathrm{~mL} / \mathrm{min}$ ) with $\mathrm{MeOH}-\mathrm{H}_{2} \mathrm{O}$ (25:75) to afford compound $\mathbf{1}$ (4.6 mg, $\left.t_{\mathrm{R}}=77.5 \mathrm{~min}\right)$. Fr. 6C (110.0 mg) was further isolated by preparative HPLC on a YMC HPLC column $(5 \mu \mathrm{m}, 20.0 \times 250 \mathrm{~mm}$, flow rate $8 \mathrm{~mL} / \mathrm{min})$ with $\mathrm{MeOH}-\mathrm{H}_{2} \mathrm{O}(30: 70)$ to afford compound 2 (36.0 mg, $\left.t_{\mathrm{R}}=59.5 \mathrm{~min}\right)$. Fr. $6 \mathrm{E}(120.0 \mathrm{mg})$ was also further purified by preparative HPLC on a YMC HPLC column $(5 \mu \mathrm{m}, 20.0 \times 250 \mathrm{~mm}$, flow rate $8 \mathrm{~mL} / \mathrm{min})$ with $\mathrm{MeOH}-\mathrm{H}_{2} \mathrm{O}$ (35:65) to afford compound 3 $\left(50.0 \mathrm{mg}, t_{\mathrm{R}}=26.0 \mathrm{~min}\right)$ and compound $4\left(2.0 \mathrm{mg}, t_{\mathrm{R}}=15.0 \mathrm{~min}\right)$. Compound $5\left(12.0 \mathrm{mg}, t_{\mathrm{R}}=60.0 \mathrm{~min}\right)$ 
was obtained from Fr. $6 \mathrm{G}$ by preparative HPLC on a YMC HPLC column $(5 \mu \mathrm{m}, 20.0 \times 250 \mathrm{~mm}$, flow rate $8 \mathrm{~mL} / \mathrm{min})$ with $\mathrm{MeOH}-\mathrm{H}_{2} \mathrm{O}(15: 85)$.

\subsection{Compound characterization}

Magnoliaterpenoid A (1): colorless gum; $[\alpha]_{\mathrm{D}}^{20}-28.8$ (MeOH, 0.10); UV $\lambda_{\max } \mathrm{nm}(\log \varepsilon): 217$ (0.8); IR (iTR): 3367, 2943, 2879, 1682, 1652, 1424, 1203, $1140 \mathrm{~cm}^{-1} ;{ }^{1} \mathrm{H}-$ and ${ }^{13} \mathrm{C}-\mathrm{NMR}$, see Table 1; HRESIMS: $m / z=381.1301\left[\mathrm{M}+\mathrm{Cl}^{-},\left(\mathrm{C}_{16} \mathrm{H}_{26} \mathrm{O}_{8} \mathrm{Cl}\right.\right.$, calcd.381.1310).

Magnoliaterpenoid B (2): colorless gum; $[\alpha]_{\mathrm{D}}^{20}-13.4(\mathrm{MeOH}, 0.72)$; UV $\lambda_{\max } \mathrm{nm}(\log \varepsilon)$ : 203 (0.5); IR (iTR): 3345, 2969, 2917, 2884, 1385,1367, 1073, 918, 860 $\mathrm{cm}^{-1} ;{ }^{1} \mathrm{H}$ - and ${ }^{13} \mathrm{C}-\mathrm{NMR}$, see Table 1; HRESIMS: $m / z=367.1519\left[\mathrm{M}+\mathrm{Cl}^{-},\left(\mathrm{C}_{16} \mathrm{H}_{28} \mathrm{O}_{7} \mathrm{Cl}\right.\right.$, calcd.367.1518).

Magnoliaterpenoid C (3): colorless gum; $[\alpha]_{\mathrm{D}}^{20}-15.5(\mathrm{MeOH}, 1.0) ; \mathrm{UV} \lambda_{\max } \mathrm{nm}(\log \varepsilon): 240$ (0.8); IR (iTR): 3364, 2973, 2923, 2886, 1655, 1368, 1073, $904 \mathrm{~cm}^{-1}$; ${ }^{1} \mathrm{H}-$ and ${ }^{13} \mathrm{C}-\mathrm{NMR}$, see Table 1; HRESIMS: $m / z=365.1357\left[\mathrm{M}+\mathrm{Cl}^{-},\left(\mathrm{C}_{16} \mathrm{H}_{26} \mathrm{O}_{7} \mathrm{Cl}\right.\right.$, calcd. 365.1361).

Magnoliaterpenoid D (4): colorless gum; $[\alpha]_{\mathrm{D}}^{20}-6.6(\mathrm{MeOH}, 0.03) ; \mathrm{UV} \lambda_{\max } \mathrm{nm}(\log \varepsilon)$ : 202 (0.6); IR (iTR): 3362, 2926, 2871, 1100, $995 \mathrm{~cm}^{-1} ;{ }^{1} \mathrm{H}$ - and ${ }^{13} \mathrm{C}-\mathrm{NMR}$, see Table 1; HRESIMS: $\mathrm{m} / \mathrm{z}=357.1878[\mathrm{M}+\mathrm{Na}]^{+}$, $\left(\mathrm{C}_{16} \mathrm{H}_{30} \mathrm{O}_{7} \mathrm{Na}\right.$, calcd. 357.1883).

\subsection{Acid Hydrolysis and Sugar Analysis}

Compounds 1-4 (1.0 mg, respectively) were refluxed with $8 \% \mathrm{HCl}(2 \mathrm{~mL})$ for $3 \mathrm{~h}$. After the reaction mixture was extracted with EtOAc $(2 \mathrm{~mL} \times 3)$, the aqueous layer was dried under vacuum. Then the residue was dissolved in pyridine $(0.3 \mathrm{~mL})$ containing L-cysteine methyl ester hydrochloride $(1.5 \mathrm{mg})$ and heated at $60^{\circ} \mathrm{C}$ for $1 \mathrm{~h}$. A $0.3 \mathrm{~mL}$ solution of phenyl isothiocyanate $(1.5 \mathrm{mg})$ in pyridine was added to the mixture, which was heated at $60{ }^{\circ} \mathrm{C}$ for $1 \mathrm{~h}$. The reaction mixture was directly analyzed by gas chromatography (GC). The D-configuration of glucose was confirmed by comparing the retention time with a standard sample $\left[t_{\mathrm{R}}(\mathrm{min})\right.$ : D-glucose (8.5)].

\subsection{Antimicrobial Assay}

The antimicrobial activity of compounds 1-4 was evaluated against Gram-positive bacteria (Staphylococcus aureus ATCC25923), Gram-negative bacteria (Escherichia coli ATCC35150 and Proteus vulgaris ATCC33420) and fungi (Aspergillusniger ATCC6257 and Candida albicans ATCC90029) by a microdilution titre technique [19]. Kanamycin and fluconazole was used as positive controls. All tests were performed in triplicate.

\section{Conclusions}

In conclusion, although these four new compounds did not show antimicrobial activity at the tested concentration range of $1.95-250 \mu \mathrm{g} / \mathrm{mL}$, the aglycones of these four new compounds possess seven-membered rings system which are very rare and a plausible biogenetic pathway of 1-4 was proposed via the biogenetic isoprene rule. This kind of skeleton was also isolated from the Magnoliaceae for the first time.

Supplementary Materials: Supplementary materials can be accessed at: http://www.mdpi.com/1420-3049/21/ 6/728/s1.

Acknowledgments: This work was supported by the Key Project of Chinese Ministry of Education of China (2003078).

Author Contributions: W.-S.F. and Y.-H.H. conceived and designed the experiments; Y.-H.H. performed the experiments; X.-K.Z., J.-C.W., Y.-G.C. and Y.-L.Z. analyzed the data; K.S. contributed reagents/materials/analysis tools; W.-S.F. wrote the paper. All authors read and approved the final manuscript.

Conflicts of Interest: The authors declare that there are no conflicts of interest. 


\section{References}

1. Cai, H.M.; Fan, W.; Wang, X.D. Research progress on chemical constituents and pharmacological effects of Magnolia. China Pharm. 2013, 22, 3735-3737.

2. Chinese Pharmacopoeia Commission. The Pharmacopoeia of the People's Republic of China, 2015 ed.; China Medical Science Press: Beijing, China, 2015; Part I; p. 182.

3. Shen, Y.; Pang, E.C.K.; Xue, C.C.L.; Zhao, Z.Z.; Lin, J.G.; Li, G.G. Inhibitions of mast cell-derived histamine release by different Flos Magnoliae species in rat peritoneal mast cells. Phytomedicine 2008, 15, 808-814. [CrossRef] [PubMed]

4. Zhu, X.W.; Yang, J.K.; Hu, D.W. Summarize of study on the application in medicine function and the ingredient of Magnolia liliflora. Strait Pharm. J. 2002, 14, 5-7.

5. Tsuruga, T.; Ebizuka, Y.; Nakajima, J.; Chun, Y.T.; Noguchi, H.; Irtaka, Y.; Sankawa, U. Biologically active constituents of Magnolia salicifolia: Inhibitiors of induced histamine release from Rat Mast Cells. Chem. Pharm. Bull. 1991, 39, 3265-3271. [CrossRef] [PubMed]

6. Kim, G.C.; Lee, S.G.; Park, B.S.; Kim, J.Y.; Song, Y.S.; Kim, J.M.; Yoo, K.S.; Huh, G.Y.; Jeong, M.H.; Lim, Y.J.; et al. MagnoliaeFlos induces apoptosis of RBL-2H3 cells via mitochondria and caspase. Int. Arch. Allergy Immunol. 2003, 131, 101-110. [CrossRef] [PubMed]

7. Kimura, M.; Suzuki, J.; Yamada, T.; Yoshizaki, M.; Kikuchi, T.; Shigetoshi, K.; Matsuda, S. Anti-inflammatory effect of neolignans newly isolated from the Crude Drug “Shin-i” (Flos Magnoliae). Planta Med. 1985, $291-293$. [CrossRef] [PubMed]

8. Kobayashi, S.; Kimura, I.; Kimura, M. Inhibitory effect of Magnosalin derived from Flos Magnoliae on tube formation of rat vascular endothelial cells during the angiogenic process. Biol. Pharm. Bull. 1996, 19, 1304-1306. [CrossRef] [PubMed]

9. Kuroyanagi, M.; Yoshida, K.; Yamamoto, A.; Miwa, M. Bicyclo[3.2.1]octane and 6-Oxabicyclo[3.2.2]nonane type neolignans from Magnolia denudate. Chem. Pharm. Bull. 2000, 48, 832-837. [PubMed]

10. Ma, Y.L.; Han, G.Q. Biologically active lignans from Magnolia biondii Pamp. China J. Chin. Mater. Med. 1995, 20, 102-104.

11. Liang, Z.; Yang, E.Y. The therapeutic effects of irrigating therapy with magnolia injection on chronic maxillary sinusitis experimentally induced among rabbits. Chinese J. Otolaryngol. Integr. Tradit. West. Med. 2005, 13, 6-10.

12. Lee, J.; Lee, D.; Jang, D.S.; Nam, J.W.; Kim, J.P.; Park, K.H.; Yang, M.S.; Seo, E.K. Two new stereoisomers of tetrahydrofuranoid lignans from the Flower Buds of Magnolia fargesii. Chem. Pharm. Bull. 2007, 55, 137-139. [CrossRef] [PubMed]

13. Lee, J.; Seo, E.K.; Jang, D.S.; Ha, T.J.; Kim, J.P.; Nam, J.W.; Bae, G.; Lee, Y.M.; Yang, M.S.; Kim, J.S. Two new stereoisomers of neolignan and lignin from the Flower Buds of Magnolia fargesii. Chem. Pharm. Bull. 2009, 57, 298-301. [CrossRef] [PubMed]

14. Schühly, W.; Skarbina, J.; Kunert, O.; Nandi, O.I.; Bauer, R. Chemical characterization of Magnolia biondii. Nat. Prod. Commun. 2009, 4, 231-234. [PubMed]

15. Chen, Y.Y.; Wang, B.; Cao, C.Y.; Qiao, L.; Han, G.Q. Study on the hydrophilic components of Magnolia biondii Pamp. Acta Pharm. Sin. 1994, 29, 506-510.

16. Lee, J.; Kim, N.H.; Nam, J.W.; Lee, Y.M.; Jang, D.S.; Kim, Y.S.; Nam, S.H.; Seo, E.K.; Yang, M.S.; Kim, J.S. Scopoletin from the Flower Buds of Magnolia fargesii inhibits protein glycation, aldose reductase, and cataractogenesis ex vivo. Arch. Pharm. Res. 2010, 33, 1317-1323. [CrossRef] [PubMed]

17. Liang, W.J.; Ma, Y.B.; Geng, C.A.; Huang, X.Y.; Xu, H.B.; Zhang, X.M.; Chen, J.J. Paeoveitols A-E from Paeonia veitchii. Fitoterapia 2015, 106, 36-40. [CrossRef] [PubMed]

18. Youn, U.J.; Lee, J.; Nam, J.W.; Lee, Y.J.; Seo, E.K. Identification of a new isomer of dihydrophaseic acid 3'-O- $\beta$-D-glucopyranoside from Nelumbo nucifera. Bull. Korean Chem. Soc. 2011, 32, 4083-4085. [CrossRef]

19. Rahman, M.M.; Gray, A.I. A benzoisofuranone derivative and carbazole alkaloids from Murraya koenigii and their antimicrobial activity. Phytochemistry 2005, 66, 1601-1606. [CrossRef] [PubMed]

Sample Availability: Samples of the compounds 1-4 are available from the authors.

(C) 2016 by the authors; licensee MDPI, Basel, Switzerland. This article is an open access article distributed under the terms and conditions of the Creative Commons Attribution (CC-BY) license (http://creativecommons.org/licenses/by/4.0/). 